Check for updates

New York, USA

Cite this as: BMJ 2021;372:n850 http://dx.doi.org/10.1136/bmj.n850 Published: 29 March 2021

\title{
Covid-19: US cases rise while vaccinations increase
}

\section{Janice Hopkins Tanne}

The US reported more than 61 ooo cases of covid-19 per day in the past week, an increase of $12 \%$ over the average two weeks ago, even as vaccinations were increasing to about 2.5 million a day, according to the New York Times. ${ }^{1}$

Cases are high and rising in 26 states and are increasing in three other states that had a low number of cases. As of 28 March, there have been more than 30.2 million cases of covid-19 and 548 ooo deaths in the US.

The US is in a race between vaccinating people and the increasing number of cases, a particular worry as variants are spreading. So far, about one third of Americans (91 million) have had at least one dose of the approved vaccines: the two dose Pfizer BioNTech and Moderna vaccines and the single dose Johnson and Johnson vaccine. Most states expect to meet President Joe Biden's promise of making all Americans eligible for vaccination by 1 May. ${ }^{2}$

The Biden administration announced a \$1obn (£7.23bn; €8.48bn) investment to expand access to vaccines, especially to communities that are hardest hit and at high risk. The funding will increase vaccine access to communities of colour, rural areas, and populations with low incomes. ${ }^{3}$

There are concerns, however, that Johnson and Johnson may not be able to deliver the 20 million doses of its vaccine promised by the end of this month, and might not be able to ship the doses before late April. ${ }^{4}$ The Food and Drug Administration gave an emergency use authorization for a Catalent Pharma plant in Indiana to produce and ship the Johnson and Johnson vaccine, increasing the supply. ${ }^{5}$

Many states have been reopening fully and lifting rules on mask wearing and crowds despite warnings from Anthony Fauci, director of the National Institute of Allergy and Infectious Diseases, and Rochelle Walensky, director of the Centers for Disease Control and Prevention. They both urged people to continue wearing masks, keeping their distance, and avoiding crowds.

Fauci said he was often asked if the US was turning the corner on the pandemic. He said, "My response is that we are at the corner. Whether or not we turn the corner remains to be seen. We do have a lot of challenges in front of us regarding the high level of daily infections." Walensky said she was enthusiastic about the pace of vaccinations but said, "What concerns me is what is happening with the spring breakers and people who are not continuing to implement prevention strategies." ${ }^{6}$ After Florida lifted most of its restrictions, large numbers of young people gathered in Miami Beach last week during spring break (a vacation period for students), prompting the city to declare a state of emergency and call in armed police to break up crowds. ${ }^{7}$
1 Coronavirus in the US: latest map and case count. New York Times. 28 March 2021. www.nytimes.com/interactive/2020/us/coronavirus-us-cases.html.

2 Covid-19: about a third of US adults have received at least one dose of a vaccine. New York Times. 28 March 2021. www.nytimes.com/live/2021/03/27/world/covid-vaccine-coronavirus-cases.

3 Fact Sheet. Biden administration announces historic \$10billion investment to expand access to covid-19 vaccines and build confidence in hardest-hit and highest-risk communities. White House. 25 March 2021. www.whitehouse.gov/briefing-room/statements-releases/2021/03/25/fact-sheetbiden-administration-announces-historic-10-billion-investment-to-expandaccess-to-covid-19-vaccines-and-build-vaccine-confidence-in-hardest-hitand-highest-risk-communities.

4 Banco E, Owermohle S, Roubein R. Biden administration frets /\& may miss vaccine goal. 22 March 2021. www.politico.com/news/2021/03/22/bidenadministration-frets-j-j-may-miss-vaccine-goal-477602.

5 Knutson J. US approves Johnson \& Johnson covid vaccine plant. Axios. 24 March 2021. www.axios.com/fda-johnson-johnson-coronavirus-vaccineeddd663c-3c79-481e-a270-121b758b6f0a.html.

$6 \quad$ Kopp E. Fauci: US may “turn the corner” on virus, but spring break poses big risks. Roll Call. 24 March 2021. https://rollcall.com/2021/03/24/faucius-may-turn-the-corner-on-virus-but-spring-break-poses-big-risks.

7 Majchrowicz M, Burch ADS. Miami Beach welcomed revelers. Then came the crackdown. New York Times. 24 March 2021. www.nytimes.com/2021/03/24/us/miami-covid-19-spring-break.html.

This article is made freely available for use in accordance with BMJ's website terms and conditions for the duration of the covid-19 pandemic or until otherwise determined by BMJ. You may use, download and print the article for any lawful, non-commercial purpose (including text and data mining) provided that all copyright notices and trade marks are retained. 